\title{
Analisis Kemampuan Berpikir Kritis Matematis : Dampak Pendekatan Saintifik ditinjau dari Kemandirian Belajar
}

\author{
Alkat Yanwar'1, Abi Fadila1 \\ ${ }^{1}$ Universitas Islam Negeri Raden Intan Lampung. Jalan Endro Suratmin, Sukarame, Bandar \\ Lampung35133, Indonesia. \\ *Corresponding Author. E-mail: yanwaralkat@yahoo.co.id
}

\begin{abstract}
Abstrak
Tujuan dalam penelitian ini yaitu untuk mengetahui apakah terdapat: (1) pengaruh pendekatan saintifik terhadap kemampuan berpikir kritis matematis peserta didik; (2) pengaruh kemandirian belajar terhadap kemampuan berpikir kritis matematis peserta didik; (3) interaksi antara pendekatan saintifik dan kemandirian belajar terhadap kemampuan berpikir kritis matematis peserta didik. Penelitian ini merupakan penelitian quasy eksperimental design dengan desain faktorial $2 \times 3$. Teknik pengambilan sampel dalam penelitian ini menggunakan probability sampling dengan cluster random sampling. Instrumen penelitian yang digunakan adalah angket kemandirian belajar dan tes kemampuan berpikir kritis matematis. Data hasil tes kemampuan berpikir kritis matematis dianalisis menggunakan uji anava dua jalan sel tak sama dan uji lanjut yang menggunakan uji komparasi ganda dengan metode Scheffe'. Hasil penelitian menunjukkan bahwa: (1) terdapat pengaruh pendekatan saintifik terhadap kemampuan berpikir kritis matematis peserta didik; (2) terdapat pengaruh kemandirian belajar terhadap kemampuan berpikir kritis matematis peserta didik; (3) tidak terdapat interaksi antara pendekatan saintifik dan kemandirian belajar terhadap kemampuan berpikir kritis matematis.
\end{abstract}

Kata Kunci: Kemampuan Berpikir Kritis Matematis, Kemandirian Belajar, Pendekatan Saintifik.

\begin{abstract}
The purpose of this study is to find out whether there are: (1) the influence of the scientific approach on students' critical thinking skills; (2) the influence of learning independence on students' mathematical critical thinking ability; (3) the interaction between the scientific approach and the learning independence of students' critical thinking skills. This research is a quasy experimental design research with $2 \times 3$ factorial design. Sampling technique in this research use probability sampling with cluster random sampling. The research instrument used is questionnaire self-reliance learning and test of critical thinking ability mathematically. Data from the results of tests of mathematical critical thinking ability were analyzed using anava test of two unequal cell paths and further tests using a double comparison test with the Scheffe method. The results showed that: (1) there was an influence of the scientific approach on students' critical thinking skills; (2) there is influence of learning independence to students' critical thinking ability mathematically; (3) there is no interaction between the scientific approach and the learning independence of mathematical critical thinking skills.
\end{abstract}

Keywords: Mathematical Critical Thinking Skill, Learning Independence, Scientific Approach

\section{PENDAHULUAN}

Pembelajaran

memiliki peranan mengembangkan kemampuan berpikir kritis. Berpikir kritis merupakan bagian dari kemampuan berpikir tingkat tinggi 
yang sangat esensial bagi kehidupan dan pekerjaan (Anggraeni, Prayitno, \& Ariyanto, 2016). Kemampuan berpikir kritis dapat dikembangkan melalui pembelajaran matematika di sekolah atau pun perguruan tinggi, yang menitik beratkan pada system, struktur, konsep, prinsip, serta kaitan yang ketat antara suatu unsur dan unsur lainnya (Kurniasih, 2017; Maulana, 2008). Kemampuan berpikir kritis diperlukan peserta didik untuk membantu menyelesaikan persoalan yang ada dalam kehidupan sehari-hari. Kemampuan berpikir kritis matematis tidak hanya menekankan peserta didik pada kemampuan menyelesaikan masalah, namun juga kemampuan peserta didik dalam mengevaluasi penyelesaian masalah, peserta didik mampu mengevaluasi kebenaran penyelesaian masalah tersebut. Pada saat ini masih ada siswa yang memiliki kemampuan berpikir kritis matematis rendah sehingga mengakibatkan hasil nilai matematika peserta didik di bawah Kriteria Ketuntasan Minimal (KKM). Untuk mengatasi rendahnya kemampuan berpikir kritis matematis peserta didik, perlu diadakan suatu identifikasi permasalahan dan memberikan solusi pada permasalahan tersebut. Oleh sebab itu sangat dibutuhkan pembelajaran yang tepat untuk mengakomodasi peningkatan kompetensi siswa sehingga hasil belajar dapat lebih baik khususnya kemampuan berpikir kritis matematis.

Salah satu pendekatan yang dapat mengembangkan kemampuan berpikir kritis matematis peserta didik adalah pendekatan saintifik. Pendekatan saintifik atau lebih umum dikatakan pendekatan ilmiah merupakan pendekatan dalam implementasi kurikulum 2013 (Nuralam
\& Eliyana, 2017; Pratama, 2017). Pembelajaran dengan pendekatan saintifik adalah proses pembelajaran yang dirancang sedemikian rupa agar peserta didik secara aktif mengonstruk konsep, hukum atau prinsip melalui tahapantahapan mengamati, merumuskan masalah, mengajukan atau merumuskan hipotesis, mengumpulkan data, menganalisis data, menarik kesimpulan dan mengomunikasikan konsep, hukum atau prinsip yang ditemukan (Maduretno, Sarwanto, \& Sunarno, 2016; Palaki \& Fahinu, 2015). Kriteria proses pembelajaran saintifik adalah mendorong dan menginspirasi peserta didik berpikir secara kritis, analitis, dan tepat dalam mengidentifikasi, memahami, memecahkan masalah, dan mengaplikasikan substansi atau materi pembelajaran.

Selain pada pembelajaran di kelas, perlu ditinjau juga pada diri peserta didik sendiri, salah satu hal yang harus ditinjau pada diri peserta didik yaitu kemandirian belajar. Kemandirian belajar peserta didik akan membantu peserta didik mengenali dirinya dan menjadi manajer dalam belajarnya, sehingga kemampuan berpikir kritis matematis peserta didik dapat meningkat seiring dengan meningkatnya kemandirian belajar peserta didik (Ainiyah, Suyitno, \& Winarti, 2018). Kemandirian belajar adalah suatu keadaan dimana seseorang memiliki hasrat bersaing untuk maju demi kebaikan dirinya, mampu mengambil keputusan, berinisiatif untuk mengatasi masalah yang dihadapi, memiliki kepercayaan diri dalam mengerjakan tugas-tugas, dan bertanggung jawab atas apa yang dilakukannya (Nurhayati, 2011). Kemandirian belajar peserta didik dapat dikembangkan melalui langkah-langkah 
pendekatan saintifik. langkah-langkah pembelajaran dengan pendekatan saintifik yaitu mengamati, menanya, mengumpulkan data, mengasosiasi, dan mengomunikasikan. Kemandirian belajar dapat dilatihkan kepada peserta didik salah satunya melalui kegiatan mengumpulkan data. Mereka secara mandiri mencari informasi dari berbagai sumber belajar.

Berdasarkan penelitian yang dilakukakan oleh (Tawil, Ismaimuza, \& Rochaminah, 2014), menunjukkan bahwa penerapan pendekatan saintifik dapat meningkatkan pemahaman belajar siswa pada pembelajaran matematika. Begitu juga penelitian yang dilakukan oleh (Efriana, 2014), menunjukkan bahwa penerapan pendekatan saintifik dapat meningkatkan hasil belajar siswa dan keaktifan siswa selama mengikuti proses pembelajaran matematika.

Telah banyak dilakukan penelitian menggunakan pendekatan saintifik. Pendekatan saintifik dapat memberikan pengaruh signifikan terhadap hasil belajar (Ismawati \& Mulyaningsih, 2014; Marjan, Arnyana, \& Setiawan, 2014; Sawitri, Suardika, \& Ardana, 2015; Tiyani, Suardika, \& Ardana, 2015), minat belajar (Sukerti, Marhaeni, \& Suarni, 2015), motivasi belajar (Siswati, 2017; Sumayasa, Marhaeni, \& Dantes, 2015), prestasi belajar (Hastuti, 2017; Katimo, Suparmi, \& Sukarmin, 2016), kemampuan komunikasi matematis dan berpikir kreatif siswa (Widiani, Rif'at, \& Ijuddin, 2016), sikap spiritual siswa (Widnyani, Dantes, \& Tegeh, 2015; Wigunanta, Dantes, \& Tegeh, 2015), sikap sosial siswa (Sariasih, Dantes, \& Tegeh, 2015), pemecahan masalah matematika
(Sintadevi, Sedanayasa, \& Japa, 2015), kemampuan pemecahan masalah dan kemampuan berpikir tingkat tinggi (Erny, Haji, \& Widada, 2017), sikap berpikir ilmiah (Ratunguri, 2015), keterampilan berpikir kritis siswa (Meilani, Hunaepi, \& Mirawati, 2017).

Berdasarkan uraian diatas dan penelitian terdahulu maka penulis melakukan penelitian pengaruh pendekatan saintifik terhadap kemampuan berpikir kritis matematis peserta didik. Keterbaharuan dalam penelitian ini menggunakan tinjauan yaitu kemandirian belajar. Penelitian ini bertujuan untuk mengetahui apakah terdapat: (1) pengaruh pendekatan saintifik terhadap kemampuan berpikir kritis matematis peserta didik; (2) pengaruh kemandirian belajar terhadap kemampuan berpikir kritis matematis peserta didik; (3) interaksi antara pendekatan saintifik dan kemandirian belajar terhadap kemampuan berpikir kritis matematis peserta didik.

\section{METODE}

Penelitian ini merupakan penelitian quasy eksperimental design dengan desain faktorial $2 \times 3$. Adapun rancangan dalam penelitian ini dapat digambarkan sebagai berikut: 
Desimal, 2 (1), 2019 - 12

Alkat Yanwar, Abi Fadila

Tabel 1. Desain Faktorial Penelitian

\begin{tabular}{cccc}
\hline Kemandirian Belajar & & & \\
& Tinggi $\left(\mathrm{B}_{1}\right)$ & Sedang $\left(\mathrm{B}_{2}\right)$ & Rendah $\left(\mathrm{B}_{3}\right)$ \\
$\begin{array}{c}\text { Pendekatan Pembelajaran } \\
\text { Pendekatan Saintifik }\left(\mathrm{A}_{1}\right)\end{array}$ & $\left(\mathrm{A}_{1} \mathrm{~B}_{1}\right)$ & $\left(\mathrm{A}_{1} \mathrm{~B}_{2}\right)$ & $\left(\mathrm{A}_{1} \mathrm{~B}_{3}\right)$ \\
Pendekatan Konvensional $\left(\mathrm{A}_{2}\right)$ & $\left(\mathrm{A}_{2} \mathrm{~B}_{1}\right)$ & $\left(\mathrm{A}_{2} \mathrm{~B}_{2}\right)$ & $\left(\mathrm{A}_{2} \mathrm{~B}_{3}\right)$ \\
\hline
\end{tabular}

Keterangan:

\begin{tabular}{|c|c|c|c|c|c|c|}
\hline $\mathrm{A} i$ & \multicolumn{6}{|c|}{ : Pendekatan Pembelajaran } \\
\hline $\mathrm{Bj}$ & \multicolumn{6}{|c|}{ : Kemandirian Belajar } \\
\hline $\mathrm{A}_{1}$ & \multicolumn{6}{|c|}{ : Pendekatan Pembelajaran Saintifik } \\
\hline $\mathrm{A}_{2}$ & \multicolumn{6}{|c|}{ : Pendekatan Pembelajaran Konvensional } \\
\hline $\mathrm{B}_{1}$ & \multicolumn{6}{|c|}{ : Kemandirian Belajar Tinggi } \\
\hline $\mathrm{B}_{2}$ & \multicolumn{6}{|c|}{ : Kemandirian Belajar Sedang } \\
\hline $\mathrm{B}_{3}$ & \multicolumn{6}{|c|}{ : Kemandirian Belajar Rendah } \\
\hline $\mathrm{A}_{1} \mathrm{~B}_{1}$ & \multicolumn{6}{|c|}{ : Kemandirian Belajar Tinggi melalui Pendekatan Pembelajaran Saintifik } \\
\hline $\mathrm{A}_{1} \mathrm{~B}_{2}$ & \multicolumn{6}{|c|}{ : Kemandirian Belajar Sedang melalui Pendekatan Pembelajaran Saintifik } \\
\hline $\mathrm{A}_{1} \mathrm{~B}_{3}$ & \multicolumn{6}{|c|}{ : Kemandirian Belajar Rendah melalui Pendekatan Pembelajaran Saintifik } \\
\hline $\mathrm{A}_{2} \mathrm{~B}_{1}$ & $\begin{array}{l}\text { : Kemandirian } \\
\text { Konvensional }\end{array}$ & Belajar & Tinggi & melalui & Pendekatan & Pembelajaran \\
\hline $\mathrm{A}_{2} \mathrm{~B}_{2}$ & $\begin{array}{l}\text { : Kemandirian } \\
\text { Konvensional }\end{array}$ & Belajar & Sedang & melalui & Pendekatan & Pembelajaran \\
\hline$A_{2} B_{3}$ & $\begin{array}{l}\text { : Kemandirian } \\
\text { Konvensional }\end{array}$ & Belajar & Rendah & melalui & Pendekatan & Pembelajaran \\
\hline
\end{tabular}

Dalam penelitian ini peserta didik dibagi menjadi dua kelompok. Kelompok pertama adalah kelompok eksperimen, yaitu peserta didik yang mendapat perlakuan pembelajaran matematika dengan pendekatan saintifik. Kelompok kedua adalah kelompok kontrol, yaitu peserta didik yang mendapat perlakuan pembelajaran matematika dengan pendekatan konvensional. Teknik pengambilan sampel dalam penelitian ini menggunakan probability sampling dengan cluster random sampling. Instrumen penelitian yang digunakan adalah angket kemandirian belajardan tes kemampuan berpikir kritis matematis. Uji coba instrumen terdiri dari uji validasi isi dan validasi konstruk (validitas, reliabilitas, tingkat kesukaran, dan daya beda). Teknik analisis data yang digunakan dalam penelitian yaitu menggunakan uji anava dua jalan sel tak sama (Novalia \& Syazali, 2013). Dengan hipotesis sebagai berikut:

1) $\mathrm{H}_{0 \mathrm{~A}}$ ditolak jika $F_{A ; o b s}>F \alpha$

2) $\mathrm{H}_{0 \mathrm{~B}}$ ditolak jika $F_{B ; o b s}>F \alpha$

3) $\mathrm{H}_{0 \mathrm{AB}}$ ditolak jika $F_{A B ; o b s}>F \alpha$

Selanjutnya dilakukan analisis dua variabel untuk melihat apakah terdapat efek utama pada pendekatan pembelajaran dan kemampuan berpikir kritis serta interaksi

1) $H_{O A}: \alpha_{i}=0$ untuk setiap $i=1,2$ 
(tidak terdapat pengaruh pendekatan saintifik terhadap kemampuan berpikir kritis matematis) $H_{1 A}$ : paling sedikit ada satu $\alpha_{i}$ yang tidak nol

(terdapat pengaruh pendekatan saintifik

terhadap kemampuan berpikir kritis matematis)

2) $H_{O B}: \beta_{i}=0$ untuk setiap $j=1,2,3$

(tidak terdapat pengaruh pada peserta didik yang memiliki kategori kemandirian belajar tinggi, sedang, rendah terhadap kemampuan berpikir kritis matematis)

$H_{1 B}$ : paling sedikit ada satu $\beta_{i}$ yang tidak nol

(terdapat pengaruh pada peserta didik yang memiliki kategori kemandirian belajar tinggi, sedang, rendah terhadap kemampuan berpikir kritis matematis)

3) $H_{O A B}:(a \beta)_{i j}=0$ untuk setiap $i=1,2$ dan $j=1,2,3$

(tidak terdapat interaksi antara perlakuan pembelajaran dengan kategori kemandirian belajar tinggi, sedang, rendah peserta didik terhadap kemampuan berpikir kritis matematis)

$H_{1 A B}$ : paling sedikit ada satu $(a \beta)_{i j} \neq$ 0

(terdapat interaksi antara perlakuan pembelajaran dengan kategori kemandirian belajar tinggi, sedang, rendah peserta didik terhadap kemampuan berpikir kritis matematis)

Apabila setelah dilakukan uji ANAVA Dua Jalur dan didapatkan keputusan uji $\mathrm{H}_{0}$ ditolak, maka dilakukan uji komparasi ganda menggunakan metode scheffe' dengan hipotesis sebagai berikut:
1) $H_{O A}: \alpha_{1}=\alpha_{2}$

(tidak terdapat pengaruh kemampuan berpikir kritis matematis antara peserta didik yang memiliki kemandirian belajar tinggi dengan peserta didik yang memiliki kemandirian belajar sedang) $H_{1 A}: \alpha_{1} \neq \alpha_{2}$ : paling sedikit ada satu $\alpha_{i}$ yang tidak nol

(terdapat pengaruh kemampuan berpikir kritis matematis antara peserta didik yang memiliki kemandirian belajar tinggi dengan peserta didik yang memiliki kemandirian belajar sedang)

2) $H_{O B}: \beta_{1}=\beta_{2}=\beta_{3}$

(tidak terdapat pengaruh kemampuan berpikir kritis matematis antara peserta didikyang memiliki kemandirian belajar tinggi dengan peserta didik yang memiliki kemandirian belajar rendah)

$H_{1 B}: \beta_{j} \neq 0$

(terdapat pengaruh kemampuan berpikir kritis matematis antara peserta didikyang memiliki kemandirian belajar tinggi dengan peserta didik yang memiliki kemandirian belajar rendah)

3) $H_{O A B}:(a \beta)_{i j}=0$ untuk setiap $i=1,2$ $\operatorname{dan} j=1,2,3$

(tidak terdapat pengaruh kemampuan kemampuan berpikir kritis matematis yang signifikan antara peserta didik yang memiliki kemandirian belajar sedang dengan peserta didik yang memiliki kemandirian belajar rendah)

$H_{1 A B}$ : paling sedikit ada satu $(a \beta)_{i j} \neq$ 0

(terdapat pengaruh kemampuan berpikir kritis matematis yang signifikan antara peserta didik yang memiliki kemandirian belajar sedang 
dengan peserta didik yang memiliki kemandirian belajar rendah)

\section{HASIL DAN PEMBAHASAN}

Data yang dimaksud dalam penelitian ini adalah hasil yang diperoleh dari tes akhir yang diberikan pada kedua kelas sampel, yaitu kelas eksperimen dan kelas kontrol. Dari skor hasil tes belajar siswa pada kedua kelas dilakukan perhitungan rata-rata, simpangan baku (S), hasil perhitungan dapat dilihat pada Tabel 2:

Tabel 2. Deskripsi Data Skor Kemampuan Berpikir Kritis Matematis Kelas Eksperimen dan Kelas Kontrol

\begin{tabular}{|c|c|c|c|c|c|c|c|}
\hline \multirow{2}{*}{ Kelompok } & \multirow{2}{*}{$\mathbf{X}_{\text {maks }}$} & \multirow{2}{*}{$\mathbf{X}_{\min }$} & \multicolumn{3}{|c|}{ Ukuran Tendensi Sentral } & \multicolumn{2}{|c|}{$\begin{array}{l}\text { Ukuran } \\
\text { Dispersi }\end{array}$} \\
\hline & & & $\overline{\boldsymbol{X}}$ & $M_{o}$ & $M_{e}$ & $\mathbf{R}$ & $\mathbf{S}$ \\
\hline $\begin{array}{c}\text { Eksperimental } \\
\text { Kontrol }\end{array}$ & $\begin{array}{l}93 \\
86\end{array}$ & $\begin{array}{l}58 \\
30\end{array}$ & $\begin{array}{l}75,03 \\
63,16\end{array}$ & $\begin{array}{l}75 \\
68\end{array}$ & $\begin{array}{c}75,5 \\
65\end{array}$ & $\begin{array}{l}35 \\
56\end{array}$ & $\begin{array}{l}10,34 \\
14,89\end{array}$ \\
\hline
\end{tabular}

Pada tabel di atas dapat dilihat bahwa skor rata-rata peserta didik pada kelas eksperimen lebih besar dari skor ratarata peserta didik pada kelas kontrol, dan simpangan baku skor peserta didik pada kelas eksperimen lebih kecil dari pada simpangan baku pada kelas kontrol. Jadi, dapat diambil kesimpulan bahwa kelas eksperimen lebih baik dari kelas kontrol. Kemudian, untuk mengetahui hipotesis ini diterima atau ditolak maka penulis membandingkan hasil tes kemampuan berpikir kritis matematis peserta didik pada kelas eksperimen dengan hasil tes kemampuan berpikir kritis matematis peserta didik pada kelas kontrol. Rumus yang digunakan yaitu uji ANAVA dua arah. Untuk menggunakan Anava dua arah terlebih dahulu dilakukan uji normalitasdan homogenitas kedua kelas sampel.

\section{Uji Normalitas}

Uji normalitas dilkukan untuk mengatahui apakah sempel berasal dari populasi yang berdistribusi normal atau tidak, untuk itu dilakukan uji normalitas terhadap hasil tes kemampuan berpikir kritis matematis peserta didik pada kelas eksperimen dan kelas kontrol.Uji normalitas data dilakukandengan menggunakan Uji Liliefors. Hasil uji normalitas dari kedua sampel dapat dilihat pada Tabel 3:

Tabel 3. Uji Normalitas Data Kemampuan Berpikir Kritis Matematis

\begin{tabular}{clccc}
\hline No & \multicolumn{1}{c}{ Kelompok } & Lmaks & $\mathbf{L}_{\mathbf{0}, 05 ; \mathbf{n}}$ & Keputusan Uji \\
1 & Eksperimen & 0,090 & 0,161 & $\mathrm{H}_{0}$ diterima \\
2 & Kontrol & 0,063 & 0,159 & $\mathrm{H}_{0}$ diterima \\
3 & Kemandirian belajar & 0,139 & 0,258 & $\mathrm{H}_{0}$ diterima \\
& Tinggi & 0,138 & $\mathrm{H}_{0}$ diterima \\
\hline & Kemandirian belajar & 0,077 & 0 & \\
\hline
\end{tabular}


Desimal, 1 (1), 2018 - 15

Alkat Yanwar, Netriwati, Abi Fadila

\begin{tabular}{|c|c|c|c|c|}
\hline 5 & $\begin{array}{l}\text { Kemandirian belajar } \\
\text { Rendah }\end{array}$ & 0,112 & 0,258 & $\mathrm{H}_{0}$ diterima \\
\hline
\end{tabular}

Berdasarkan hasil perhitungan tersebut terlihat $L_{\text {hitung }} \leq L_{\text {tabel }}$ maka, $\mathrm{H}_{0}$ diterima sehingga disimpulkan bahwa kedua kelas sampel berdistribusi normal.

2. Uji Homogenitas

Uji homogenitas ini digunakan untuk mengetahui apakah kedua kelas sampel mempunyai variansi yang sama atau tidak. Uji homogenitas tes akhir kemampuan berpikir kritis matematis peserta didik dilakukan dengan menggunakan rumus uji Bartlett dengan hipotesis $\mathrm{H}_{0}: \sigma_{1}^{2}=\sigma_{2}^{2}$ dan $\sigma_{i}^{2} \neq \sigma_{j}^{2}$, kriteria pengujian terima hipotesis $\mathrm{H}_{0} \mathrm{jika} \quad \chi_{\text {hitung }}^{2}<\chi_{\alpha, k-1}^{2}$ yang berarti bahwa variansinya homogenitas. Uji variansi kedua kelas tersebut adalah $\chi^{2}=$ $\frac{2.203}{c}\left(f \log R K G-\sum_{j=1}^{k} f_{i} \log S_{j^{2}}\right)$.

Selanjutnya hasil perhitungan uji homogenis dari kedua sampel dapat dilihat pada Tabel 4:

Tabel 4. Hasil Uji Homogenitas

\begin{tabular}{clccc}
\hline No & \multicolumn{1}{c}{ Kelompok } & $\chi \mathbf{2}_{\text {hitung }}$ & $\chi \mathbf{2}_{\text {table }}$ & Kesimpulan \\
1 & $\mathrm{~A}_{1}$ dan $\mathrm{A}_{2}$ & 3,770 & 3,841 & Homogen \\
2 & $\mathrm{~B}_{1}, \mathrm{~B}_{2}$ dan $\mathrm{B}_{3}$ & 3,837 & 5,991 & Homogen \\
3 & $\mathrm{~A}_{1} \mathrm{~B}_{1}, \mathrm{~A}_{1} \mathrm{~B}_{2}$ dan $\mathrm{A}_{1} \mathrm{~B}_{3}$ & 0,627 & 5,991 & Homogen \\
4 & $\mathrm{~A}_{2} \mathrm{~B}_{1}, \mathrm{~A}_{2} \mathrm{~B}_{2}$ dan $\mathrm{A}_{2} \mathrm{~B}_{3}$ & 3,022 & 5,991 & Homogen \\
5 & $\mathrm{~A}_{1} \mathrm{~B}_{1}$ dan $\mathrm{A}_{2} \mathrm{~B}_{1}$ & 3,161 & 3,841 & Homogen \\
6 & $\mathrm{~A}_{1} \mathrm{~B}_{2}$ dan $\mathrm{A}_{2} \mathrm{~B}_{2}$ & 3,626 & 3,841 & Homogen \\
7 & $\mathrm{~A}_{1} \mathrm{~B}_{3}$ dan $\mathrm{A}_{2} \mathrm{~B}_{3}$ & 0,587 & 3,841 & Homogen \\
\hline
\end{tabular}

Keterangan:

A1 : Kelompok Eksperimen

A2 : Kelompok Kontrol

B1 : Kelompok Kemandirian Belajar Tinggi

B2 : Kelompok Kemandirian Belajar Sedang

B3 : Kelompok Kemandirian Belajar Rendah

Berdasarkan hasil perhitungan tersebut terlihat bahwa $\chi_{\text {hitung }}^{2} \leq \chi_{\text {tabel }}^{2}$ maka, $\mathrm{H}_{0}$ diterima, artinya ketiga sampel dengan kategori tinggi, sedang dan rendah berasal dari populasi yang sama (homogen).

\section{Uji Hipotesis}

Dari hasil uji prasyarat diperoleh bahwa kelas eksperimen dan kelas kontrol merupakan sampel yang berasal dari populasi yang berdistribusi normal dan
homogen.Setelah uji prasyarat dilakukan uji analisis variansi dua jalan sel tak sama.Hasil analisis data pada uji analisis variansi dua jalan sel tak sama dapat dilihat pada Tabel 5 sebagai berikut: 
Desimal, 1 (1), 2018 - 16

Alkat Yanwar, Netriwati, Abi Fadila

Tabel 5. Analisis Variansi Dua Jalan Sel Tak Sama

\begin{tabular}{lccccc}
\multicolumn{1}{c}{ Sumber } & JK & Dk & RK & F & Fit \\
Model Pembelajaran (A) & 816,7066 & 1 & 816,7066 & 6,381256 & 4,016195 \\
Kemandirian Belajar (B) & 3593,637 & 2 & 1796,819 & 14,03927 & 3,164993 \\
Interaksi (AB) & 72,47462 & 2 & 36,23731 & 0,283137 & 3,164993 \\
Galat (G) & 7039,188 & 55 & 127,9852 & - & - \\
Total (T) & 11522,01 & 60 & - & - & - \\
\hline
\end{tabular}

Berdasarkan analisis variansi dua jalan sel tak sama di atas dapat disimpulkan bahwa:

1) Berdasarkan perhitungan analisis variansi dua jalan sel tak sama bahwa nilai $F_{h i t}=6,381256$ dan $\mathrm{F}_{\mathrm{a}}=4,016195$. Hal ini menunjukkan bahwa $F_{\text {hit }}$ yang diperoleh lebih besar dari $\mathrm{F}_{\text {tabel. }}$ Dengan demikian berarti terdapat pengaruh pendekatan pembelajaran saintifik terhadap kemampuan berpikir kritis matematis, sehingga $\mathrm{H}_{0 \mathrm{~A}}$ ditolak.

2) Berdasarkan perhitungan analisis variansi dua jalan sel tak sama bahwa $\mathrm{F}_{\text {hit }}=14,03927$ dan $\mathrm{F} \alpha=$ 3,164993 . Hal ini menunjukkan bahwa nilai $F_{h i t}$ yang diperoleh lebih besar dari $F_{\text {tabel. }}$ Dengan demikian, terdapat pengaruh pada peserta didik yang memiliki kategori kemandirian belajar tinggi, sedang dan rendah terhadap kemampuan berpikir kritis matematis, sehingga $\mathrm{H}_{0 \mathrm{~B}}$ ditolak.

3) Berdasarkan perhitungan analisis variansi dua jalan sel tak sama bahwa $F_{\text {hit }}=0,283137$ dan $\mathrm{F} \alpha=$ 3,164993. Hal ini menunjukkan bahwa nilai $F_{h i t}$ yang diperoleh lebih kecil dari $\mathrm{F}_{\text {tabel. }}$ Dengan demikian, tidak terdapat interaksi antara pendekatan pembelajaran dengan kategori kemandirian belajar terhadap kemampuan berpikir kritis matematis, sehingga $\mathrm{H}_{0 \mathrm{AB}}$ diterima.

Berdasarkan hasil uji analisis variansi dua jalan sel tak sama yang menunjukkan bahwa terdapat keputusan uji hipotesis nol ditolak. Maka dilakukan tindak uji lanjut yang menggunakan metode scheffe'.

Hipotesis nol ditolak terjadi antar kolom yaitu $\mathrm{H}_{0 \text { в }}$ ditolak, maka tidak semua kemandirian belajar memberikan efek terhadap kemampuan berpikir kritis matematis. Dengan kata lain, pasti terdapat paling sedikit dua rerata yang tidak sama. Karena dalam penelitian ini peneliti mengambil tiga tipe kemandirian belajar yaitu kemandirian belajar tinggi, kemandirian belajar sedang, dan kemandirian belajar rendah, maka uji komparasi ganda perlu dilakukan untuk melihat yang secara signifikan memberikan rerata yang berbeda. Data amatan yang digunakan dalam perhitungan komparasi ganda dengan metode scheffe' merupakan hasil uji analisis variansi dua jalan sel tak sama yang berasal dari data rerata tiap sel dan rerata marginal. Analisis data komparasi ganda dengan metode 
Desimal, 1 (1), 2018 - 17

Alkat Yanwar, Netriwati, Abi Fadila

scheffe' dapat dilihat pada Tabel 6

sebagai berikut:

Tabel 6. Rataan Marginal

\begin{tabular}{lcccc}
\multicolumn{1}{c}{ Pendekatan } & \multicolumn{2}{c}{ Kemandirian Belajar Matematika } & \multirow{2}{*}{ Rembean Marginal } \\
Saintifik & Tinggi & Sedang & Rendah & 74,13 \\
Konvensional & 84,33 & 74,55 & 63,50 & 64,94 \\
Rataan Marginal & 79,00 & 63,14 & 52,67 & \\
\hline
\end{tabular}

Berdasarkan Tabel 6 di atas, peneliti akan melakukan uji komparasi ganda antar kolom yaitu pada kemandirian belajar (kemandirian belajar tinggi, kemandirian belajar sedang, dan kemandirian belajar rendah). Uji dilakukan dengan rerata marginal kemandirian belajar tinggi dengan kemandirian belajar sedang ( $\alpha_{1}$ vs $\left.\alpha_{2}\right)$, rerata marginal kemandirian belajartinggi dengan kemandirian belajarrendah ( $\alpha_{1}$ vs $\left.\alpha_{3}\right)$, dan rerata marginal kemandirian belajar sedang dengan kemandirian belajar rendah ( $\alpha_{2}$ vs $\alpha_{3}$ ). Berikut disajikan analisis data komparasi ganda antar kolom :

Tabel 7. Uji Komparasi Ganda Antar Kolom

\begin{tabular}{ccccc}
\hline No & Interaksi & F $_{\text {hitung }}$ & $\mathbf{F}_{\text {tabel }}$ & Keputusan \\
1 & $\mu_{1}$ vs $\mu_{2}$ & 10,32 & 6,33 & Ho ditolak \\
2 & $\mu_{1}$ vs $\mu_{3}$ & 21,73 & 6,33 & H$_{0}$ ditolak \\
3 & $\mu_{2}$ vs $\mu_{3}$ & 7,28 & 6,33 & Ho $_{0}$ ditolak \\
\hline
\end{tabular}

Berdasarkan hasil perhitungan uji komparasi ganda antar kolom pada Tabel 7 disimpulkan sebagai berikut:

1) Hasil perhitungan menunjukkan $F_{\text {hitung }}>F_{\text {tabel }}$ dengan nilai $F_{\text {hitung }}=10,32395$ dan $F_{\text {tabel }}=$ 6,329987. Sehingga $\mathrm{H}_{0}$ ditolak, berarti terdapat pengaruh kemampuan berpikir kritis matematis antara peserta didik yang memiliki kemandirian belajar tinggi dengan peserta didik yang memiliki kemandirian belajar sedang. Berdasarkan Tabel 6 rerata kemampuan berpikir kritis matematis peserta didik dengan kategori kemandirian belajar tinggi, sebesar 81,67 lebih besar dibandingkan rerata kemampuan berpikir kritis matematis peserta didik dengan kategori kemandirian belajar sedang, sebesar 68,85.
Sehingga peserta didik dengan kategori kemandirian belajar tinggi memiliki kemampuan berpikir kritis matematis lebih baik daripada peserta didik dengan kategori kemandirian belajar sedang.

2) Hasil perhitungan menunjukkan $F_{\text {hitung }}>F_{\text {tabel }}$ dengan nilai $F_{\text {hitung }}=21,72804$ dan $F_{\text {tabel }}=$ 6,329987. Sehingga $\mathrm{H}_{0}$ ditolak, berarti terdapat pengaruh kemampuan berpikir kritis matematis antara peserta didikyang memiliki kemandirian belajar tinggi dengan peserta didik yang memiliki kemandirian belajar rendah. Berdasarkan Tabel 6 rerata kemampuan berpikir kritis matematis peserta didik dengan kategori kemandirian belajar tinggi, sebesar 81,67 lebih besar dibandingkan rerata kemampuan 
berpikir kritis matematis peserta didik dengan kategori kemandirian belajar rendah, sebesar 58,08. Sehingga peserta didik dengan kategori kemandirian belajar tinggi memiliki kemampuan berpikir kritis matematis lebih baik daripada peserta didik dengan kategori kemandirian belajar rendah.

3) Hasil perhitungan menunjukkan $F_{\text {hitung }}>F_{\text {tabel }}$ dengan nilai $F_{\text {hitung }}=7,276594$ dan $F_{\text {tabel }}=$ 6,329987. Sehingga $\mathrm{H}_{0}$ ditolak, berarti terdapat pengaruh kemampuan berpikir kritis matematis yang signifikan antara peserta didik yang memiliki kemandirian belajar sedang dengan peserta didik yang memiliki kemandirian belajar sedang rendah. Berdasarkan Tabel 6 rerata kemampuan berpikir kritis matematis peserta didik dengan kategori kemandirian belajar sedang, sebesar 68,85 lebih besar dibandingkan rerata kemampuan berpikir kritis matematis peserta didik dengan kategori kemandirian belajar rendah, sebesar 58,08. Sehingga peserta didik dengan kategori kemandirian belajar sedang memiliki kemampuan berpikir kritis matematis lebih baik daripada peserta didik dengan kategori kemandirian belajar rendah.

Dari hasil penelitian yang dilakukan oleh peneliti didapatkan bahwa pembelajaran dengan pendekatan saintifik sangat baik apabila diterapkan dalam pembelajaran. Menurut (Abidin, 2014) ada empat tahapan dalam proses pembelajaran dengan pendekatan saintifik yaitu: (1) Identifikasi masalah; (2) Membuat hipotesis; (3) Mengumpulkan dan menganalisis data; (4) Menginterpretasi data dan membuat kesimpulan. Langkahlangkah pendekatan saintifik dalam proses pembelajaran meliputi menggali informasi melalui pengamatan, bertanya, percobaan, kemudian mengolah data atau informasi, menyajikan data atau informasi, dilanjutkan dengan menganalisis, menalar, kemudian menyimpulkan dan mencipta (Daryanto, 2014).

Berpikir kritis matematis merupakan dasar proses berpikir untuk menganalisis argumen dan memunculkan gagasan terhadap tiap makna untuk mengembangkan pola pikir secara logis (Jumaisyaroh, Napitupulu, \& Hasratuddin, 2014). Sedangkan kemandirian belajar prinsipnya sangat erat hubungannya dengan belajar menyelidiki, yaitu berupa pengarahan dan pengontrolan diri dalam memperoleh dan menggunakan pengetahuan (Miarso, 2014). Kemandirian belajar sangat penting dalam proses belajarnya siswa, masalah yang bisa terjadi dari rendahnya kemandirian belajar yaitu berdampak pada prestasi belajar siswa yang menurun, kurangnya tanggung jawab siswa dan ketergantungan terhadap orang lain dalam mengambil keputusan maupun dalam mengerjakan tugas-tugas sekolah (Lestari, Yusmansyah, \& Rahmayanthi, 2015). Berdasarkan hasil penelitian yang dilakukan oleh peneliti didapatkan bahwa peserta didik dengan kemandirian belajar tinggi dan sedang akan lebih mudah diterapkan pembelajaran dengan pendekatan saintifik dari pada dengan pendekatan konvensional, akan tetapi peserta didik dengan kemandirian belajar rendah akan cenderung sulit untuk diterapkan pendekatan pembelajaran saintifik. dari 
hasil penelitian yang dilakukan dapat dijelaskan bahwa tidak ada interaksi antara pendekatan pembelajaran dengan kemandirian belajar terhadap kemampuan berpikir kritis matematis peserta didik.

\section{SIMPULAN DAN SARAN}

Berdasarkan analisis data dan pengujian hipotesis yang telah dilakukan oleh peneliti, maka dapat disimpulkan bahwa (1) Terdapat pengaruh pendekatan saintifikterhadap kemampuan berpikir kritis matematis. Kemampuan berpikir kritis matematis peserta didik dengan menggunakan pendekatan saintifiklebih baik dibandingkan kemampuan berpikir kritis matematis peserta didik dengan menggunakan pendekatan konvensional; (2) Terdapat pengaruh antara kemandirian belajar terhadap kemampuan berpikir kritis matematis. Kemampuan berpikir kritis matematis yang memiliki kemandirian belajar tinggi lebih baik dari peserta didik yang memiliki kemandirian belajar sedang maupun rendah; (3) Tidak terdapat interaksi antara perlakuan pembelajaran dengan kategori kemandirian belajar peserta didik terhadap kemampuan berpikir kritis matematis.Interaksi hanya berpengaruh pada pendekatan pembelajaran saintifikterhadap kemampuan berpikir kritis matematis sedangkan pendekatan pembelajaran saintifik dengan kategori kemandirian belajar tidak terdapat interaksi terhadap kemampuan berpikir kritis matematis.

Berdasarkan kesimpulan di atas terdapat beberapa saran diantaranya: untuk penelitian selanjutnya dapat mencari pendekatan-pendekatan pembelajaran lain yang lebih berpengaruh terhadap kemandirian belajar ditinjau dari kemampuan berpikir kritis matematispeserta didik dan mencoba menggunakan pendekatan yang sama ataupun pendekatan-pendekatan pembelajaran lain dengan mencari pengaruh lain terhadap kemampuan afektif peserta didik. Semoga penelitian ini dapat bermanfaat dan menjadi sumber rujukan ataupun referensi untuk penelitian selanjutnya.

\section{DAFTAR PUSTAKA}

Abidin, Y. (2014). Desain Sistem Pembelajaran dalam Konteks Kurikulum 2013. Bandung: Refika Aditama.

Ainiyah, Q., Suyitno, H., \& Winarti, E. R. (2018). Analisis Kemampuan Berpikir Kritis Matematis pada Pembelajaran PSPBL Berbantuan Smart Point Ditinjau dari Kemandirian Belajar. In PRISMA Prosiding Seminar Nasional Matematika (Vol. 1, pp. 279-288).

Anggraeni, Y. N., Prayitno, B. A., \& Ariyanto, J. (2016). Penerapan Model Konstruktivis-Metakognitif pada Materi Sistem Koordinasi untuk Meningkatkan Kemampuan Berpikir Kritis Siswa Kelas XI MIA 1 SMA Negeri 6 Surakarta Tahun Pelajaran 2015/2016. Bio-Pedagogi, 5(2), 4855.

Daryanto. (2014). Pendekatan Pembelajaran Saintifik Kurikulum 2013. Yogyakarta: Gava Media.

Efriana, F. (2014). Penerapan Pendekatan Scientific untuk Meningkatkan Hasil Belajar Siswa Kelas VII MTsN Palu Barat pada Materi Keliling dan Luas Daerah Layang-Layang. Jurnal Elektronik Pendidikan Matematika Tadulako, 1(2), 170-181. 
Erny, Haji, S., \& Widada, W. (2017). Pengaruh Pendekatan Saintifik Pada Pembelajaran Matematika Terhadap Kemampuan Pemecahan Masalah dan Kemampuan Berpikir Tingkat Tinggi Siswa Kelas X IPA SMA Negeri 1 Kepahiang. Jurnal Pendidikan Matematika Raflesia, 2(1).

Hastuti, L. D. (2017). Pengaruh Pendekatan Saintifik Terhadap Prestasi Belajar IPA. Trihayu: Jurnal Pendidikan Ke-SD-An, 3(2), 107-111.

Ismawati, U. F., \& Mulyaningsih, S. (2014). Pengaruh Penerapan Pembelajaran Dengan Pendekatan Saintifik Pada Materi Elastisitas Terhadap Hasil Belajar Siswa Kelas X. Inovasi Pendidikan Fisika, 3(3), 32-35.

Jumaisyaroh, T., Napitupulu, E. E., \& Hasratuddin. (2014). Peningkatan Kemampuan Berpikir Kritis Matematis dan Kemandirian Belajar Siswa SMP melalui Pembelajaran Berbasis Masalah. Kreano, Jurnal Matematika Kreatif-Inovatif, 5(2), 157-169.

Katimo, Suparmi, \& Sukarmin. (2016). Pengaruh Pembelajaran dengan Pendekatan Saintifik Menggunakan Metode Eksperimen dan Demonstrasi Terhadap Prestasi Belajar dan Kreativitas Ditinjau dari Sikap Ilmiah. Inkuiri, 5(2), 87-93.

Kurniasih, M. D. (2017). Pengaruh Pembelajaran React Terhadap Kemampuan Berpikir Kritis Matematis Ditinjau dari Habit Of Mind Mahasiswa. KALAMATIKA Jurnal Pendidikan Matematika, 2(1), 29-38.

Lestari, Y., Yusmansyah, \& Rahmayanthi, R. (2015). Peningkatan Kemandirian Belajar Dengan Layanan Bimbingan Kelompok. ALIBKIN: Jurnal Bimbingan Konseling, 4(1).
Maduretno, T. W., Sarwanto, \& Sunarno, W. (2016). Pembelajaran Ipa Dengan Pendekatan Saintifik Menggunakan Modellearning Cycledan Discovery Learning Ditinjau dari Aktivitas dan Motivasi Belajar Siswa Terhadap Prestasi Belajar. Jurnal Pendidikan Fisika Dan Keilmuan (JPFK), 2(1), 111.

Marjan, J., Arnyana, I. B. P., \& Setiawan, I. G. A. N. (2014). Pengaruh Pembelajaran Pendekatan Saintifik Terhadap Hasil Belajar Biologi dan Keterampilan Proses Sains Siswa MA $\mathrm{Mu}$ ' allimat NW Pancor Selong Kabupaten Lombok Timur Nusa Tenggara Barat. Jurnal Pendidikan Dan Pembelajaran IPA Indonesia, 4(1).

Maulana. (2008). Pendekatan Metakognitif Sebagai Alternatif Pembelajaran Matematika Untuk Meningkatkan Kemampuan Berpikir Kritis Mahasiswa PGSD. Jurnal Pendidikan Dasar, 10, 39-46.

Meilani, R., Hunaepi, \& Mirawati, B. (2017). Pengaruh Model Pembelajaran Berbasis Masalah dengan Pendekatan Saintifik terhadap Keterampilan Berpikir Kritis Siswa. Prisma Sains: Jurnal Pengkajian Ilmu Dan Pembelajaran Matematika Dan IPA IKIP Mataram, 5(1), 20-24.

Miarso, Y. H. (2014). Menyemai Benih Teknologi Pendidikan. Jakarta: Kencana.

Novalia, \& Syazali, M. (2013). Olah Data Penelitian Pendidikan. Bandar Lampung: AURA.

Nuralam, \& Eliyana. (2017). Penerapan Pendekatan Saintifik Terhadap Kemampuan Pemecahan Masalah Matematika di SMAN 1 Darul Imarah Aceh Besar. Jurnal Ilmiah Didaktika, 
18(1), 64-76.

Nurhayati, E. (2011). Psikologi Pendidikan Inovatif. Yogyakarta: Pustaka Pelajar. Palaki, Y., \& Fahinu. (2015). Pengaruh Pendekatan Saintifik Terhadap Kemampuan Pemahaman Matematika Siswa Kelas VIII SMP Negeri 9 Kendari pada Materi Operasi Aljabar. Jurnal Penelitian Pendidikan Matematika, 3(3), 153166.

Pratama, F. W. (2017). Peran SelfRegulated Learning Dalam Memoderatori Pembelajaran dengan Pendekatan Saintifik Terhadap Hasil Belajar Siswa. Satya Widya, 33(2), 99-108.

Ratunguri, Y. (2015). Pembelajaran Berbasis Saintifik Terhadap Sikap Berpikir Ilmiah Mahasiswa Program Studi PGSD Universitas Negeri Manado. PEDAGOGIA: Jurnal Pendidikan, 4(1), 1-7.

Sariasih, L. M., Dantes, N., \& Tegeh, I. M. (2015). Pengaruh Pendekatan Saintifik Dalam Mata Pelajaran IPS Terhadap Sikap Sosial Siswa Dengan Kovariabel Intensitas Hubungan Dalam Pola Asuh Keluarga pada Siswa Kelas IV SD di Pedesaan Tahun Pelajaran 2014/2015. MIMBAR PGSD Undiksha, 3(1).

Sawitri, N. L. E., Suardika, I. W. R., \& Ardana, I. K. (2015). Pengaruh Pendekatan Saintifik Terhadap Hasil Belajar Pengetahuan IPA Tema Tempat TinggalKu Siswa Kelas IV SD Ditinjau dari Karakteristik Pertanyaan Guru. MIMBAR PGSD Undiksha, 3(1).

Sintadevi, M. N., Sedanayasa, G., \& Japa, I. G. N. (2015). Pengaruh Pendekatan Saintifik Berbasis Proyek Terhadap Pemecahan Masalah Matematika Siswa di Gugus III Desa Mambang.
MIMBAR PGSD Undiksha, 3(1).

Siswati, V. (2017). Pengaruh Pembelajaran dengan Pendekatan Saintifik terhadap Motivasi dan Prestasi Belajar Mata Pelajaran Pendidikan Agama Islam pada Kelas VII SMP Negeri 1 Wringinanom Gresik. PROGRESSA Journal of Islamic Religious Instruction, 1(1), 1-12.

Sukerti, N. N., Marhaeni, A. A. I. N., \& Suarni, N. K. (2015). Pengaruh Pembelajaran Tematik Terpadu Melalui Pendekatan Saintifik Terhadap Minat Belajar dan Hasil Belajar Siswa Kelas IV SD Negeri 2 Tibubeneng Kuta Utara. PENDASI: Jurnal Pendidikan Dasar Indonesia, 4(1).

Sumayasa, I. N., Marhaeni, A. A. I. N., \& Dantes, N. (2015). Pengaruh Implementasi Pendekatan Saintifik Terhadap Motivasi Belajar dan Hasil Belajar Bahasa Indonesia pada Siswa Kelas VI di Sekolah Dasar Se Gugus VI Kecamatan Abang, Karangasem. PENDASI: Jurnal Pendidikan Dasar Indonesia, 5(1), 1-11.

Tawil, A. H. M., Ismaimuza, D., \& Rochaminah, S. (2014). Penerapan Pendekatan Scientific Pada Model Pembelajaran Kooperatif Tipe Think Pair Share untuk Meningkatkan Pemahaman Siswa di Kelas VII SMPN 6 Palu. Jurnal Elektronik Pendidikan Matematika Tadulako, 2(1), 87-97.

Tiyani, N. L. P., Suardika, I. W. R., \& Ardana, I. K. (2015). Pengaruh Pendekatan Saintifik Terhadap Hasil Belajar Pengetahuan IPA Tema Tempat TinggalKu Ditinjau dari Karakteristik Pertanyaan Guru pada Siswa Kelas IV SD. MIMBAR PGSD Undiksha, 3(1).

Widiani, T., Rif'at, M., \& Ijuddin, R. (2016). Penerapan Pendekatan Saintifik dan 
Desimal, 2(1), 2019 - 22

Alkat Yanwar, Abi Fadila

Pengaruhnya Terhadap Kemampuan Komunikasi Matematis dan Berpikir Kreatif Siswa. Jurnal Pendidikan Dan Pembelajaran, 5(1), 1-14.

Widnyani, I. I. D. A. R., Dantes, N., \& Tegeh, I. M. (2015). Pengaruh Pendekatan Saintifik Terhadap Sikap Spiritual Siswa dengan Kovariabel Intensitas Hubungan Dalam Pola Asuh Keluarga. MIMBAR PGSD Undiksha, 3(1).

Wigunanta, B. L. D., Dantes, N., \& Tegeh, I. M. (2015). Pengaruh Pendekatan Saintifik pada Mata Pelajaran PKN Terhadap Sikap Spiritual Dengan Kovariabel Intensitas Pola Asuh. MIMBAR PGSD Undiksha, 3(1). 